\title{
Topical Ointment Dosage Form
}

National Cancer Institute

\section{Source}

National Cancer Institute. Topical Ointment Dosage Form. NCI Thesaurus. Code C91192.

A ointment intended for administration to a body surface. 